\title{
A Comparative Study of Shyamatrivruttadi Kalka and Bruhatiphala- Dwiharidra Kalka Yonipuran in Kaphaja Yonivyapad
}

\author{
Research Article
}

\begin{abstract}
Pinge CD ${ }^{1 *}$, Kulkarni CJ², Danga $\mathrm{SK}^{3}$, Bende Yogita ${ }^{4}$, Bombarde Anita ${ }^{5}$, Khandekar Anuradha ${ }^{6}$

1. PG Scholar, 2. Professor, SVNHT's Ayurved Mahavidyalaya, Rahuri Factory, Ahmednagar

3. Govt. Ayurveda College \& Hospital, Nagpur

4. Associate Professor, Department of Panchkarma, Shri Ayurveda Mahavidyalaya, Nagpur 5. Professor, Dept., of Streerog-Prasutitantra, Govt. Ayurved College \& Hospital, Nagpur 6. Assistant Professor, MGIMS, Sevagram
\end{abstract}

\begin{abstract}
Introduction: A healthy woman is a promise of healthy family. The concept of healthy yoni has been asserted in various phase of woman's life from puberty to marriage to child birth and thereafter. Due to change in lifestyle, modern food habits of fast food, junk food she is unable to follow the rules of Dincharya, Rutucharya, Rajaswala, Rutumati and Sutikaparicharya which are explained by Aacharyas for women's health. Thus she is prone to various yonirogas, one of which is Yonigat Shewta-Picchilsrava, Yonikandu, Yonigata Alpa vedana which are the features of Kaphaja yonivyapada and is neglected by women as minor symptoms. Aims and Objectives: 1.To evaluate the efficacy of Shyamatrivruttadi kalka in kaphaja Yonivyapad \& Bruhatiphala-Dwiharidra kalka in kaphaja yonivyapad. Materials and Methods: The female patients within 18 to 45 years of age group complaining mainly of kaphaja yonivyapad were selected irrespective of occupation, religion and prakruti. Conclusion: Most of the patients in experimental group showed better relief in sign symptoms as compared to the control group, it is obvious from the all analysis of data that the drug in experimental group had definitely better role than control group to alleviate clinical features in Kaphaj yonivyapad.
\end{abstract}

Keyword: Kaphaja Yonivyapada, Garbhadharan, Rajaswala, Rutucharya, Sutikaparicharya etc.

\section{Introduction:}

In the modern world, the Life style, food habit and unhygienic practice have increased stress, strain and restlessness which have resultantly expanded the spread of menstrual disorders. Ratio of Menstrual

*Corresponding Author:

Chandraprabha D.Pinge

281 "Mai" Sakkardara, Nagpur-09.

Email: drchandraprabha4156@gmail.com

Cell: 9420248023 disorder is raising in gynecological practice which precursor of infertility and other problems, so it requires more attention. Today woman is playing a pivotal role in each and every sphere, so woman's good health has to be part and parcel of her life but while catering to several requirement of today's life style woman falls prey to several ailments. Every attempt should be made to maintain healthy womanhood.

In order to give healthy progeny special attention must be given to conserver maternal health. Infections pertaining to the 
yoni are a burning problem for women irrespective of their age or socioeconomic status. We must protect her from all these diseases, so she can produce healthy well being.

A healthy woman is a promise of healthy family. The concept of healthy yoni has been asserted in various phase of woman's life from puberty to marriage to child birth and thereafter.

As mentioned in Asthanghridaya any abnormality of female genital tract is responsible for various disorders like infertility, menorrhagia, piles etc out of several gynecological disorder encroaching woman body, Kaphaja yonivyapad is one of the problem which ruins both physically and psychologically(1).

As the Stree is mula of reproduction, as Garbhadharan, Garbhaposhan and giving to baby and after that his nourishment bringing up is done by Stree her health is our prime importance which leads to plan of best Gruhasthashram.(2,3) Stree is important part of our society and family. Being Daughter, wife, mother, carrier oriented women, she plays different roles and fallows social and family responsibilities. Nature has given special role to Stree to become mother. She takes care of baby's nourishment, bringing up and her physical, mental, social growth so as to make him good human being. Along with as today's women are carrier oriented she is becoming independent, making her own decision and thus making her own space in the society. Thus in this fast life she is subjected to all sorts of physical and mental hardship. Due to change in lifestyle, modern food habits of fast food, junk food she is unable to follow the rules of Dincharya, Rutucharya, Rajaswala, Rutumati and Sutikaparicharya which are explained by Aacharyas for women's health. Thus she is prone to various yonirogas one of which is Yonigat shewta picchilsrava, Yonikandu, Yonigata Alpavedana which are the features of
Kaphaja yonivyapada and is neglected by women as minor symptoms.

Yonivyapadas are related to Tryavartayoni (4). Yonivyapadas causes Apatyavighat, because vikruti of Kshetra, of Tryavartayoni causes Garbhpat, Garbhastrva, Leenagarbh, Garbhvikruti.(5) Yonivyapada has been described in Various Literatures of Ayurveda viz. Charak Samhita (Chi.30), Sushrut Samhita (U.38), Asthtang Hridaya (U 33), Asthtang Sangraha (Uttarshan38) Madhav Nidan(63),Sharangdhar Samhita (Purvakhanda 7) Kashyap Samhita (Su.27) Bhavprakash \& Yogratnakar (Yoniraogadhikara).

As in our country due to poor nutrition, multiple childbirth, low socio-economic status, poverty, population growth, negligence of proper hygiene, many women are anemic, malnourished, ill-health. So they are prone to various yonirogas like Kaphaja yonivyapada.

\section{Aims and Objectives:}

1. To study the details about Kaphaja yonivyapad.

2. To evaluate the efficacy of Shyamatrivruttaadi kalka in Kaphaja yonivyapad.

3. To evaluate the efficacy of Bruhatiphala-Dwiharidra kalka in Kaphaja yonivyapad.

4. To compare the efficacy of Shyamatrivrutta kalka and Bruhatiphala- Dwiharidra kalka in Kaphaja yonivyapad.

\section{Materials and Methods: Clinical Study:}

Selection of Patients: The married female patients within 18 to 45 years of age group complaining mainly of Kaphaja yonivyapad were selected irrespective of occupation, religion and prakruti.

Patients having Kaphaja yonivyapad with following signs and symptoms,
a] Yonigat shweta,picchil srava.

b] Yonigata alpa vedana 
c] Yonikandu.

\section{Exclusive Criteria -}

- Patients with Intrauterine contraceptive devices and ring pessaries.

- Pregnant \& Patients with physiological white discharge \& cervical erosion.

- Patients with a major Illness like Hypertension, Diabetes, Severe Anemia, respiratory diseases \& Infections like HIV, STD, Tuberculosis, Malignancy.

Place of work
Total 60 Patient were selected from OPD and IPD from the Department of Stree Roga \& Prasutitantra of the S.V.N.H.T's Ayurved Mahavidyalaya \& Hospital, Rahuri Factory, Ahmednagar.

\section{Informed Consent \& Ethical Clearance}

An informed written consent will be obtained from every patient before including trial. Ethical clearance has been taken from IEC of the college.

Investigation: $\mathrm{CBC}, \mathrm{ESR} \&$ Urine Routine, microscopic, Blood sugar level fasting and post prandial, UPT \& HIV tests were carried out.

Table No .1 Group Management:

\begin{tabular}{|l|l|l|}
\hline Groups & Experimental group & Control Group \\
\hline Dose & 10 gm once day & 10 gm once day \\
\hline Duration & 7 day & 7 day \\
\hline Routeof administration & Per vaginally & Per vaginally \\
\hline Kala & Post Menstrual & Post Menstrual \\
\hline Groups & Shyamatrivruttaadi Kalka & Bruhatiphala-Dwiharidra Kalka \\
\hline No of Patients & 30 & 30 \\
\hline
\end{tabular}

Table No.2 Assessment Criteria: (Gradation of Symptoms):

\begin{tabular}{|c|c|c|c|}
\hline Sr.no & Observation & Criteria & Grade \\
\hline 1 & Srava Praman & $\begin{array}{l}\text { Pad is required } \\
\text { clothes get wet } \\
\text { slight discharge } \\
\text { No Discharge }\end{array}$ & $\begin{array}{l}4 \\
3 \\
2 \\
1\end{array}$ \\
\hline 2 & Sthanik Kandu & $\begin{array}{l}10 \text { or more than } 10 \text { times } \\
\text { /day } \\
6 \text { to } 9 \text { times / day } \\
1 \text { to } 5 \text { times / day } \\
\text { No itching }\end{array}$ & $\begin{array}{l}3 \\
2 \\
1 \\
0\end{array}$ \\
\hline 3 & Srava Swaroop & $\begin{array}{l}\text { Granthi } \\
\text { Tantool } \\
\text { Drava } \\
\text { No Disharge }\end{array}$ & $\begin{array}{l}3 \\
2 \\
1 \\
0\end{array}$ \\
\hline 4 & Yonigat Vedana & $\begin{array}{l}\text { Unable to do any } \\
\text { movement } \\
\begin{array}{l}\text { Continuous pain during } \\
\text { movement }\end{array}\end{array}$ & $\begin{array}{l}3 \\
2\end{array}$ \\
\hline
\end{tabular}




\begin{tabular}{|l|l|l|l|}
\hline & & $\begin{array}{l}\text { Pain precipitating form } \\
\text { time to time by heavy } \\
\text { movement } \\
\text { No pain }\end{array}$ & 1 \\
\hline 5 & Srava Gandha & $\begin{array}{l}\text { Present } \\
\text { Absent }\end{array}$ & 0 \\
\hline
\end{tabular}

Table No. 3 Symptom Flow Chart:

I] Srava Pramana [ Amout of Discharge]:-

\begin{tabular}{|l|l|l|l|}
\hline Adhik & Pads required & +++ & Grade -3 \\
\hline Madhyam & Stains undergarment & ++ & Grade -2 \\
\hline Alpa & Slight discharge & + & Grade -1 \\
\hline Absent & No discharge & - & Grade -0 \\
\hline
\end{tabular}

Relief of amount of Srava Pramana:-

\begin{tabular}{|l|l|l|l|}
\hline No Relief & Pads required & +++ & Grade -3 \\
\hline Mild Relief & Stains undergarment & ++ & Grade -2 \\
\hline Moderate Relief & Slight discharge & + & Grade-1 \\
\hline Good Relief & No discharge & - & Grade-0 \\
\hline
\end{tabular}

II] Srava Swroop:-

\begin{tabular}{|l|l|l|l|}
\hline Adhik & Granthi & +++ & Grade-3 \\
\hline Madhyam & Tantool & ++ & Grade -2 \\
\hline Alpa & Drava & + & Grade -1 \\
\hline Absent & No discharge & - & Grade -0 \\
\hline
\end{tabular}

Relief of Srava swroop-

\begin{tabular}{|l|l|l|l|}
\hline No Relief & Granthi & +++ & Grade-3 \\
\hline Mild Relief & Tantool & ++ & Grade-2 \\
\hline Moderate Relief & Drava & + & Grade-1 \\
\hline Good Relief & No discharge & - & Grade -0 \\
\hline
\end{tabular}

\section{III] Yonigata Vedana:-}

\begin{tabular}{|l|l|l|l|}
\hline Adhik & Unable to do any movement due to pain & +++ & Grade -3 \\
\hline Madhyam & Continuous paining during movement & ++ & Grade-2 \\
\hline Alpa & $\begin{array}{l}\text { Pain increases from time to tie by heavy } \\
\text { movements }\end{array}$ & + & Grade-1 \\
\hline Absent & No pain & - & Grade-0 \\
\hline
\end{tabular}

Relief of Yonigata Vedana-

\begin{tabular}{|l|l|l|l|}
\hline No Relief & Unable to do any movement due to pain & +++ & Grade -3 \\
\hline Mild Relief & Continuous paining during movement & ++ & Grade -2 \\
\hline Moderate Relief & $\begin{array}{l}\text { Pain increases from time to tie by heavy } \\
\text { movements }\end{array}$ & + & Grade -1 \\
\hline Good Relief & No pain & - & Grade-0 \\
\hline
\end{tabular}


IV] Yonikandu:-

\begin{tabular}{|l|l|l|l|}
\hline No Relief & Can't resist Itching & +++ & Grade-3 \\
\hline Mild Relief & Hamper her daily Activity & ++ & Grade -2 \\
\hline Moderate Relief & $\begin{array}{l}\text { Doesn't Hamper her daily } \\
\text { Activity }\end{array}$ & + & Grade -1 \\
\hline Good Relief & No Itching & - & Grade 0 \\
\hline
\end{tabular}

Relief from Yonikandu:-

\begin{tabular}{|l|l|l|l|}
\hline No Relief & Can't resist Itching & +++ & Grade -3 \\
\hline Mild Relief & Hamper her daily Activity & ++ & Grade -2 \\
\hline Moderate Relief & $\begin{array}{l}\text { Doesn't Hamper her daily } \\
\text { Activity }\end{array}$ & + & Grade -1 \\
\hline Good Relief & No Itching & - & Grade -0 \\
\hline
\end{tabular}

\section{Method of Kalka Preparation:}

Shyamatrivruttaadi kalka (Shyamativrutta,Aargvadha, Sudha, Tilvaka, Saptala, Shankhini Danti,Dravanti) with all drug taken together for making kalka as per guideline. Shuska dravya is powdered and filtered with cloth and mixed with appropriate quantity of water, kept in khalva yantra and made into paste form by rubbing. Kalka is taken on gauge and tampon is made. It's sterilization done.

\section{Mode of administration:}

Kalka was taken on gauge and tampon was made and it was sterilized well before insertion into vagina. Then sterile kalka was kept in yoni upto $4-5 \mathrm{~cm}$ in Lithotomic position. As kalka was tikshna it was placed for 2 hrs. Then removed and irrigation of yoni was done with lukewarm water.

\section{Follow up}

During the course of treatment all the clinical signs and symptoms were noted on day 0th, 3rd, 7th day. Examination of patients was done again on day 15 to study the recurrence of the symptoms.

\section{Mode of action-}

As kalka consists of Shyamatrivruttaadi kalka \& Bruhatiphala and Dwiharidra, so kalka having properties of Tikta rasa pradhan, Katu, Kashay rasa, Katu vipaki, ushana virya, laghu, ruksha, tikshna gunatmak.

In Kaphaja Yonivyapada following symptoms are seen-

1] Yonigata shewta, picchil Srava

2] Yonikandu

3] Yonigata alpavedana 


\section{Yonigata shewta, picchil Srava-}

Dusha Kapha causes rasa, mansa, meda, kleda dushti leading to yonigata shewta, picchil Srava. Bruhatiphal Dwiharidra kalka has kaphaghana action, due to tikta, katu rasa, katu vipak, ushana virya, it causes deepan, aampachana and srotorodhais reduced srotoshudhi is done.

By laghu, ruksha, tikshna vishad gunas srotoshadhan is done, pachan and shoshana of $k l e d a$, mansa, meda is occured which results in is reduceing yonigata shewta, picchil Srava. By Kapha, pitta, raka shodhan twak and mansa duhsti reduced and yonishodhan occurs.

\section{Yonikandu -}

Kaphadushti causes kledadushti and krimipradurbhava causing yonikandu. Tikta and katu rasa shows kledaghana and kriighana action. Laghu, ruksha, vishad gunas of tikta rasa and laghu, ruksha, ushana, tikshna gunas of katu rasa acts as kaphaghna, kledaghna and srotoshodhak and it helps to reduce yonikandu. As sampraptibhanga occurs yonidaurgandhya is also reduced.

\section{Yonigata Alpavedana-}

Yonigata alpavedana is due to apan vayudusti. Bruhatiphala, Dwiharidra are vataghna and vedanasthapak, they ultimately reduces yonigata alpavedana.

Thus Bruhatiphala Dwiharida causes sampraptibhanga of Kaphaja yonivyapada and reduces the symptoms which increase the overall quality of life of patients.

Table No.4 Showing Wilcoxon Signed Rank Test Of Symptom score of Kaphaj Yonivyapad of Experimental Group:

\begin{tabular}{|c|c|c|c|c|c|c|c|c|}
\hline \multirow{2}{*}{$\begin{array}{c}\text { Sr. } \\
\text { No }\end{array}$} & \multirow{2}{*}{ Symptoms } & \multicolumn{2}{|c|}{ Mean } & \multicolumn{2}{|c|}{ \pm SD } & \multicolumn{2}{c|}{ \pm IS Ed } & \multirow{2}{*}{ P Value } \\
\cline { 3 - 8 } & & BT & AT & BT & AT & BT & AT & \\
\hline 1. & Shwetstrav & & & & & & & \\
\hline & - Praman & 1.56 & 0.86 & 0.67 & 0.62 & 0.12 & 0.11 & $<0.0001$ \\
\hline & - Swarup & 0.70 & 0.26 & 0.46 & 0.44 & 0.08 & 0.08 & $<0.0002$ \\
\hline & - Gandha & 1.93 & 0.86 & 0.78 & 0.68 & 0.14 & 0.12 & $<0.0001$ \\
\hline 2. & Yonigat-Vedana & 1.83 & 0.63 & 0.87 & 0.55 & 0.15 & 0.10 & $<0.0001$ \\
\hline 3. & & & & & & & & \\
\hline
\end{tabular}

Effect of Therapy on Symptoms of Kaphaj Yonivyapad in Experimental Group Statistically:-

In Experimental Group, regarding Symptoms Shwetstrav Praman the Mean \pm SD value obtained Before Treatment was 1.56 0.67 and After Treatment it was changed 0.86 0.62 which was statistically moderately significant $(\mathrm{P}<0.0001)$.

Likewise in symptoms of Shwetastrav Swarup, Gandha, Yonigat Vedana Score statistically found extremely significant $(\mathrm{P}<0.0001)$. 
Table No.5 Showing Wilcoxon Signed Rank Test Of Symptom score of Kaphaj Yonivyapad of Control Group:

\begin{tabular}{|c|c|c|c|c|c|c|c|c|}
\hline \multirow{2}{*}{$\begin{array}{c}\text { Sr. } \\
\text { No }\end{array}$} & \multirow{2}{*}{ Symptoms } & \multicolumn{2}{|c|}{ Mean } & \multicolumn{2}{|c|}{ \pm SD } & \multicolumn{2}{c|}{ \pm S Ed } & \multirow{2}{*}{ P Value } \\
\cline { 3 - 8 } & BT & AT & BT & AT & BT & AT & \\
\hline 1. & Shwetstrav & & & & & & & \\
\hline & - Praman & 2.03 & 1.20 & 0.71 & 0.61 & 0.13 & 0.11 & $<0.0001$ \\
\hline & - Swarup & 1.80 & 1.03 & 0.66 & 0.61 & 0.12 & 0.11 & $<0.0001$ \\
\hline 2. & $\begin{array}{c}\text { Yonigata- } \\
\text { Vedana }\end{array}$ & 1.90 & 1.66 & 0.71 & 0.83 & 0.13 & 0.15 & $<0.0001$ \\
\hline 3. & \begin{tabular}{c} 
Yonigata-kandu \\
\cline { 3 - 7 }$n$
\end{tabular} & 2.03 & 1.33 & 0.71 & 0.75 & 0.13 & 0.13 & $<0.0001$ \\
\hline
\end{tabular}

Effect Of Therapy On Symptoms of Kaphaj Yonivyapad in Control Group Statistically:-

In Control Group, regarding Symptoms Shwetstrav Praman the Mean \pm SD value

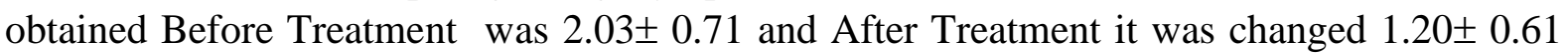
which was statistically extremely significant $(\mathrm{P}<0.0001)$.

Likewise Shwetastrav Swarup \& gandha, Yonigat Vedana, Yonigatakandu was statistically extremely significant $(\mathrm{P}<0.0001)$.

Table No.6 Showing Comparison between Two Group w.r.t Symptoms Score of 60 Patients of Kaphaj Yonivyapad

By Wilcoxon-Mann-Whitney Test

\begin{tabular}{|c|c|c|c|c|c|c|c|}
\hline Sr. & Symptoms & \multicolumn{2}{|c|}{ Mean+SD } & U & U & SEd & P Value \\
\cline { 3 - 4 } No. & Score & Gr-A & Gr-B & & & & \\
\hline 1. & Shwetastrav & & & & & & \\
\hline & - Praman & $1.6 \pm 0.56$ & $0.83 \pm 0.59$ & 713.5 & 186.5 & 0.10 & $<0.001$ \\
\hline & - Swarup & $0.7 \pm 0.65$ & $0.7 \pm 0.62$ & 477 & 423 & 0.11 & $>0.05$ \\
\hline & - Gandha & $0.43 \pm 0.50$ & $0.36 \pm 0.49$ & 480 & 420 & 0.09 & $>0.05$ \\
\hline 2. & Yonivedana & $1.06 \pm 0.58$ & $0.73 \pm 0.63$ & 573 & 327 & 0.10 & $<0.05$ \\
\hline 3. & Yonikandu & $1.2 \pm 0.71$ & $0.7 \pm 0.59$ & 619 & 280 & 0.12 & $<0.005$ \\
\hline
\end{tabular}

The Difference between before treatment and after treatment score of both group compared by 'Wilcoxon-Mann-Whitney Test'. It was found that the sum of rank of experimental group for the symptoms Shwetastrav swarup U' was 477, Test statistic (U) was 423, and SEd was 0.11 where the test statistic $U$ was between Population Mean \pm 1.96 SD which was insignificant at $5 \%$ level of significance. ( $\mathrm{P}>0.05)$ Therefore the difference between Symptoms Score of Shwetastrav swarup of Experimental and Control group is statistically insignificant, so therefore we can conclude that both groups were equally effective statistically. While in Shweta sravpraman $\mathrm{p}$ value is $<0.001$ where test statistic $\mathrm{U}$ value is 713 which was significant at 5 level of significance hence in the symptoms of shwetstravpraman, yonivedana and yonikandu in experimental group treatment is extremely found to be effective as compare to control group. 
Assessment of Clinical Result in Percentage:

1. Table No. 7 Classification of patients according to Srava Praman in Trial group:-

\begin{tabular}{|l|l|l|}
\hline Srava praman & Before Treatment & After Treatment \\
\hline Alpa & $02(06.67 \%)$ & $18(60.00 \%)$ \\
\hline Madhyam & $13(43.33 \%)$ & $06(20.00)$ \\
\hline Adhik & $15(50.00)$ & 00 \\
\hline Normal & 0 & $06(20.00 \%)$ \\
\hline
\end{tabular}

There were 15(50\%) patients having adhik shwetstrav and $13(43.33 \%)$ patients were having madhyam type of strav and after treatment it decrease up to only 6 patients having madhyam strav while 18 patients came to Alpa strav followed by 6(20\%) patients came to normal.

2. Table No. 8 Classification of patients according to Yonikandu in Trial group:-

\begin{tabular}{|l|l|l|}
\hline Yonikandu & Before Treatment & After Treatment \\
\hline Absent & $02(6.67 \%)$ & $05(16.67 \%)$ \\
\hline Alpa & $08(26.67 \%)$ & $14(46.67 \%)$ \\
\hline Madhyam & $13(43.33 \%)$ & $11(36.67 \%)$ \\
\hline Adhik & $07(23.33 \%)$ & 00 \\
\hline
\end{tabular}

After treatment $11(36.67 \%)$ patients were having moderate kandu i.e. 14 (46.67\%) patients were having alpa kandu while kandu was absent in 5(16.67\%) patients.

3. Table No. 9 Classification of patients according to Yonigata vedana in Trial group:-

\begin{tabular}{|l|c|l|}
\hline Yonigatvedana & Before Treatment & After Treatment \\
\hline Absent & 00 & $09(30.00 \%)$ \\
\hline Alpa & $10(33.33 \%)$ & $16(53.33 \%)$ \\
\hline Madhyam & $12(40.00 \%)$ & $05(16.67 \%)$ \\
\hline Adhik & $08(26.67 \%)$ & 00 \\
\hline
\end{tabular}

After treatment $05(16.67 \%)$ patients were having madhyam type of vedana, 16 $(53.33 \%)$ patients were having alpa vedana while $09(30.00 \%)$ relief from yonigata vedana. It is due to trial group drug effects as it has shulaghna properties which help in reducing yonigatvedana in maximum patients.

4. Table No.10 Classification of patients according to Gandha in Trial group:-

\begin{tabular}{|l|l|l|}
\hline Gandha & Before Treatment & After Treatment \\
\hline Present & $21(70.00 \%)$ & $08(26.67 \%)$ \\
\hline Absent & $09(30.00 \%)$ & $22(73.33 \%)$ \\
\hline
\end{tabular}

Before treatment strav gandha was present in 21(70\%) patients while after treatment it reduced and only 08(26.67\%) patients was having gandha while 22(73.33\%) having absent the gandha of strav.

\section{Effect on Symptoms Score:-}

In experimental group the significant symptomatic relief i.e. statistically significant result was observed in most of the symptoms vi. Shwetstrav in terms of praman while near 
about same result obtained in both group for the Shweta strav swarup and gandh after administration of Shyamatrivruttaadi Kalka. However yonivedana and yoni kandu were more relived in experimental group as compared to control group.

Therefore the difference between Symptoms Score of Shweta strav swarup of Experimental and Control group is statistically insignificant, so we can conclude that both groups were equally effective statistically however in the symptoms of shwetstrav praman, yonivedana and yonikandu in experimental group treatment is extremely found to be effective as compare to control group.

\section{Total Effect of Therapy:}

Table No.11 Showing Percentage of Relief in Each Symptoms of 60 Patients of KaphajYonivyapad

\begin{tabular}{|c|c|c|c|c|c|c|c|c|c|}
\hline \multirow{2}{*}{$\begin{array}{l}\text { Sr. } \\
\text { No. }\end{array}$} & \multirow[t]{2}{*}{ Symptoms } & \multicolumn{4}{|c|}{ Experimental Group } & \multicolumn{4}{|c|}{ Control Group } \\
\hline & & BT & AT & Diff & $\begin{array}{l}\% \text { of } \\
\text { Relief }\end{array}$ & BT & AT & Diff & $\begin{array}{l}\% \text { of } \\
\text { Relief }\end{array}$ \\
\hline 1 & Shwetstrav & & & & & & & & \\
\hline & a. Praman & 73 & 25 & 48 & 65.75 & 61 & 36 & 25 & 40.98 \\
\hline & b. Swarup & 47 & 26 & 21 & 44.68 & 54 & 31 & 23 & 42.59 \\
\hline & c. Gandha & 21 & 08 & 13 & 61.90 & 20 & 09 & 11 & 55.00 \\
\hline 2 & YonigatVedana & 58 & 26 & 32 & 55.17 & 57 & 35 & 22 & 38.60 \\
\hline 3 & Yonigatakandu & 55 & 19 & 36 & 65.45 & 61 & 40 & 21 & 34.42 \\
\hline
\end{tabular}

Table No.12 Showing Total Effect of therapy in 60 Patients of Kaphaj Yonivyapad

\begin{tabular}{|l|l|c|c|c|c|c|c|}
\hline \multirow{2}{*}{ No } & Effect Of Therapy & \multicolumn{3}{|c|}{ No. Of Patients } & \multicolumn{3}{c|}{ Percentage \% } \\
\cline { 3 - 8 } & & E.G. & C.G. & Total & E.G. & C.G. & Total \\
\hline 1. & $\begin{array}{l}\text { Markedly Improved (Relief } \\
>75 \%)\end{array}$ & 05 & 02 & 07 & 16.67 & 06.67 & 11.67 \\
\hline 2. & $\begin{array}{l}\text { Moderate improved (Relief by50- } \\
75 \%)\end{array}$ & 15 & 10 & 25 & 50.00 & 33.33 & 41.67 \\
\hline 3. & $\begin{array}{l}\text { Mild improved (Relief by 25- } \\
50 \%)\end{array}$ & 09 & 15 & 24 & 30.00 & 50.00 & 40.00 \\
\hline 4. & No improvements (Relief <25\%) & 01 & 03 & 04 & 03.33 & 10.00 & 06.67 \\
\hline 5. & L.A.M.A. & 00 & 00 & 00 & 00 & 00 & 00 \\
\hline
\end{tabular}

While assessing the total effect of therapy in experimental group, $16.67 \%$ patients were markedly improved, $50 \%$ were moderately, $30 \%$ mild improved while $03.33 \%$ was not improved.

While assessing the total effect of therapy in control group $6.67 \%$ patients were markedly improved, $33.33 \%$ were moderately, $50 \%$ mild improved while $10 \%$ was not improved.

Totally, $11.67 \%$ patients were markedly improved, $41.67 \%$ patients moderately, $40 \%$ were mild improved and $6.67 \%$ were unchanged.

\section{Side Effect:-}

In the study of 30 patients of experimental group no patient developed any side effect during the period of trial. However only two patients were having local irritation after treatment with kalka in control group and this was very minor just relieved within 2-3 hours.

\section{Conclusion}

After the present study, Most of the patients in experimental group showed better relief in sign symptoms as compared to the control group, 
It is obvious from the all analysis of data that the drug in experimental group had definitely better role than control group to alleviate clinical features in Kaphaj Yonivyapad, so it can be concluded that Shyamatrivruttaadi Kalka's yonipuran is reasonably effective on Kaphaja Yoniyapada as compare to BruhatiphalaDwiharidra Kalka Yonipuran.

\section{References:}

1. Kashinath Shashtri and Dr. Gorakhnath Chaturvedi, Charaka Samhita - Vidhyotini Hindi Comm. by Pt. aukhambha Bharati Academy, Varanasi, Eighth edition 1992.

2. Charak Samhita, English translation by Gulabkuvarba Ayurvedic Society.

3. Charak Samhita, Ayurved Deepika Vyakhya Nirmays Sagar Press, Bombay.

4. Sarma R.K. Bhagavandasa, Charak Samhita, Chaukhambha Sanskrta series, English translation, Varanasi. 2003.

5. Arundatta,Ashtang Hridaya with the commentaries Sarvangasundara of and Ayurvedarasayana of Hemadri, Chaukhambha Surbharti Prakashan, Varanasi, 6th Ed., 1935.

6. Kaviraj Atridev Gupt, Ashtanga Samgraha Hindi Vyakhya, Krishnadas Academy, Varanasi, 1993.

7. Prof. K.R. Srikanth ,Ashtang Samgraha of Vagbhatt (text English translation notes) by Murthy, Vol II.

8. Harshmohan Textbook of Pathology, Jaypee Brothers Medical publisher EMCA House, Delhi.

9. Madhavakara,Madhava Nidana by with Madhukosha commentary by Vijayarakshita, published by Motilala Banarasidasa, Delhi, 1st Edition.

10. Ranjeetray Desai, Nidana Chikitsa Hastamalaka published by Shri Baidanatha Bhavana, Pvt.Ltd. Calcutta. 1st edition 1953.

11. Bhavaprakasha by Bhavamisara Rajvaidya Prabhashankar Nam-Bhatta,
Transalater - Shastri Girijashankar Mayashankar, Sastushahitya Vardhak Karyalay, 1966.

12. Bhava Prakasha, Vidhyayotini Bhasa Tika, Sanita, Dr. Hariprasada Pandyan Chokhambha Sanskrita Shirija 5th edition 1980.

13. Bhavamishra and Chunekar K. C.,Bhava Prakash Nighantu, Hindi Comm., Chaukhambha Bharati Academy, Varanasi, 1988.

14. Bhela Samhita, Venkat Subrahmany Shastri, CCRIMH, New Delhi,

15. Acharya Priyavata Sharama Dravyaguna Vigyana, Chaukhambha Bharati Academy Varanasim, 1997.

16. Dhanvantri Nighantu -P.V. Sharma,Chaukhambha Bharati Academy, Varanasi 1998.

17. Yadunandan Upadhyay,Madhava Nidana with Madhukosh Sanskrit comm.Vidytotini Hindi comm. by Chaukhambha. Sanskrit Series, Nineteenth edition 1990.

18. Dr. Govindaprasad Upadhyay,Rogi Roga Pariksha Paddhati by published by Chaukhamba Surabharati Prakashana, Varanasi. 2nd edition 2001.

19. Sapeksha Nidana (Differential Diagnosis) by Dr. Govindprasad Upadhyay published by Arpita Prakashana, Nagpur 1st edition 2002.

20. Raj Nighantu, edited with Dravya, Guna Prakashita hindi Comm. Pandit Narhari, Varanasi, 1st edition 1982.

21. Dr. Smt. Shallja Srivastava, Sharangdhara "Jivamprada" hindi comm. by Chaukhambha Orientlia 2nd edition 1998.

22. Kaviraj Ambikadatt,Sushruta Samhita, Ayurveda Tantra Sandipika hindi comm.by Shasatri, Chaukhambha Sanskrit Sansthan, Varansi, 11th edition 1997.

23. Laxmipathi Shashtri Yogratnakar Published by Chaukhanba Sanskruti.in 1999. 
24. Dr. D. C. Dutta,Text book of Gynecology by, Published by New Central Book Agency, Calcutta. Edition2nd, 2000.

25. Dr. Shashank V. Parulekar, Differential Diagnosis and Management Options in Gynecology and Obstetrics by Published by Popular Prakashan, Mumbai. Edition 3rd, 2000.

26. V.G.Padubiri and Girish N.Daftary, Shaw's Textbook of Gynecology by
Published by Elsevier, New Delhi. Edition13th.2001

27. B. K. Mahajan, Methods in Biostatistics by Published by Jaydee Brothers.2003.

Conflict of Interest: None declared

Acknowledgement:

Principal, S.V.N.H.T's Ayurved Mahavidyalaya Rahuri Factory, Ahmednagar. 